Article

\title{
Exploring Farmers' Insight on Cropping Pattern for Sustainable Crop Production in Char Area of Bangladesh
}

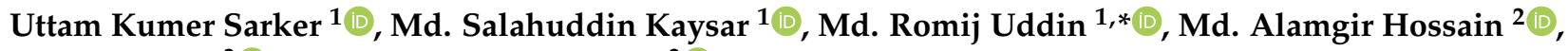 \\ Sabry Hassan ${ }^{3}$ (D) and Mohamed M. Hassan ${ }^{3}$ (i) \\ 1 Department of Agronomy, Bangladesh Agricultural University, Mymensingh 2202, Bangladesh; \\ uttam@bau.edu.bd (U.K.S.); kaysar29@gmail.com (M.S.K.) \\ 2 Department of Crop Botany, Bangladesh Agricultural University, Mymensingh 2202, Bangladesh; \\ alamgircbot@bau.edu.bd \\ 3 Department of Biology, College of Science, Taif University, P.O. Box 11099, Taif 21944, Saudi Arabia; \\ hassan@tu.edu.sa (S.H.); m.khyate@tu.edu.sa (M.M.H.) \\ * Correspondence: romijagron@bau.edu.bd
}

check for

updates

Citation: Sarker, U.K.; Kaysar, M.S.;

Uddin, M.R.; Hossain, M.A.; Hassan, S.; Hassan, M.M. Exploring Farmers' Insight on Cropping Pattern for Sustainable Crop Production in Char Area of Bangladesh. Sustainability 2022, 14, 1745. https://doi.org/ $10.3390 /$ su14031745

Academic Editor: Anastasios Michailidis

Received: 16 November 2021

Accepted: 30 January 2022

Published: 2 February 2022

Publisher's Note: MDPI stays neutral with regard to jurisdictional claims in published maps and institutional affiliations.

Copyright: (C) 2022 by the authors. Licensee MDPI, Basel, Switzerland. This article is an open access article distributed under the terms and conditions of the Creative Commons Attribution (CC BY) license (https:// creativecommons.org/licenses/by/ $4.0 /)$.

\begin{abstract}
Bangladesh is principally an agricultural country, where most people depend primarily upon their own farm production for endurance. In the char area, agriculture is multifaceted and labor-intensive, with a non-developed market, few technologies, and insufficient resources. Moreover, agroecological situations are multifarious for crop production. A study was performed in the chars of Rangpur, Gaibandha, Kurigram, and Lalmonirhat districts of Bangladesh to determine the existing situation of cropping patterns, farmers' problems with crop cultivation, and probable solutions to minimize risk in crop production. Farmers, local leaders, and dealers, as well as both government and non-government personnel, were occupied in the study to congregate information on different aspects of crop production. The study indicated that the most dominant cropping pattern was T. AmanMaize-Jute. Flood is the major climatic risk alleged by char dwellers. Additionally, char respondents are vulnerable, with more landless farmers, and dominated by crop cultivation compared to other professional work. In response to the accessible crop production risks, the char peoples are suggested to utilize some adjustment strategies in agriculture, such as implementing new or alternative cropping practices, rapid disease and pest management techniques, and cultivating short-duration varieties. The other outcomes of the study were designed to implement program planning and livelihood development of char people through attaining food security.
\end{abstract}

Keywords: char; flooding pattern; basic problems; cropping pattern; sustainable production

\section{Introduction}

Bangladesh is the biggest delta in the world, as it is within overflow plains of three large rivers. The major portion of the country is surrounded by the rivers Padma, Brahmaputra-Jamuna, and Meghna [1]. The hydro-morphological system of Bangladesh is contributed by these rivers dumping a considerable amount of silt into the Bay of Bengal. The chars, which may be distinct as the lands expanded due to the accumulation of regularly Himalayan sediments on the riverbed, are the consequence of the hydro-morphological dynamics of these rivers. The provisional sandbars that emerged in the Bengal Delta, which are $>100 \mathrm{~m}$ across with approximately ten years, are known as char [2]. The overall land area was improved in Bangladesh by $4 \%$ from 1948 to 2006, typically due to the retrieval of char lands [3]. About 10 million char inhabitants generally survive generally on agriculture; a few of them are most defenseless and the poorest people. They carry on their livelihood with hardship [4]. The entire char lands are unsteady and face yearly flooding as the chars are supposed to land erosion and produced through the frequent siltation on the major rivers. The majority of the plant nutrients in the soils are scarce, having very low organic matter contents and low moisture-holding capacity, particularly in the northern 
char region of Bangladesh [5]. Several reports also exist that intermittently revealed the current conditions of the char lands in general $[2,6,7]$.

The climatic condition, soil category, rainfall, accessibility of irrigation facilities and other inputs, transport and marketing facilities, and the development of agro-industries determine the cropping patterns in char areas. The approach against threats in char areas can be minimized by practising a diversified cropping pattern. Cautious and suitable utilization of limited resources help to boost up adjustment and production of agricultural commodities in the society over a long period. Implementation of an improved cropping pattern (Wheat-Jute-T. Aman) replacing an existing one (Fallow-Fallow-T. Aman) was appropriate in char regions for increasing crop productivity and cropping intensity [8]. Diversified cropping systems accentuated crop production in char areas [9].

To ensure farming and food security sustainably, scheduling land use for cropping is the most crucial obligation based on available agricultural lands. The crops and cropping are assorted mostly due to the flooding pattern and land types [10]. Therefore, a proper understanding of the land-use system based on the cropping system is vital for suitable intervention in sustainable way. A diversified crop cultivation process with good soil management and a step-up of educational facilities are the possible ways of attaining seasonal food security in the char region [11]. The food security condition of households of landless char people depends on the cropping pattern practised, the quantity of crop production, and their food security condition [12]. In this circumstance, existing cropping patterns with a diversity of such intricate agricultural areas are extremely important for hazard minimization and productivity enhancement.

The production and livelihood patterns of char people are quite different from plane land inhabitants. The people in the char lands are more vulnerable to frequent floods and socioeconomic conditions than those living in areas with sudden flooding [13]. The insight of char people concerning their livelihood pattern and their ability to minimize and prioritize the adjustment option for lessening their susceptibility led the people to alter cropping patterns with seasons and chosen moment of cultivation after forecasts of natural catastrophe, in order to lessen the shock of natural adversities [14]. However, a complete report that reproduces the actual agricultural troubles in the char lands and confines the technological requirement for resolving the problems therein is still inadequate. The present study was, therefore, undertaken to gather information on the diversity of crops and cropping and the agricultural problems existing in char areas with the aim of supporting plans for future agricultural development of the large areas of char land of Bangladesh.

\section{Materials and Methods}

This paper coalesces outcomes from a survey of 950 farmers of char area of the northern region of Bangladesh across nineteen administrative units of four districts, with a conversation of the government and non-government personnel and farmers, which were accomplished as part of a Swiss contact and Taif University Researchers Supporting Project.

\subsection{Study Site}

The char lands emerged with the accumulation of sediments accepted by the three forceful rivers, namely the Padma, the Brahmaputra-Jamuna, and the Meghna, and their branches. The land category and soil character apparently differ with the origin of the rivers. The char area of Gaibandha and Kurigram districts characterized the Brahmaputra, the Jamuna, and the Tista rivers, and Lalmonirhat and Rangpur district symbolized only the Tista River (Figure 1). Therefore, chars of nineteen administrative units were considered for the study because they are representative of the chars surrounding the major rivers of the country. The areas of char lands in studied regions were predicted with the information existing at the administrative units level and confirmed with the report prepared by the Department of Agricultural Extension (DAE), the largest community institute functioning for disseminating agricultural technology at the farmers' level, and presented at Table 1. 


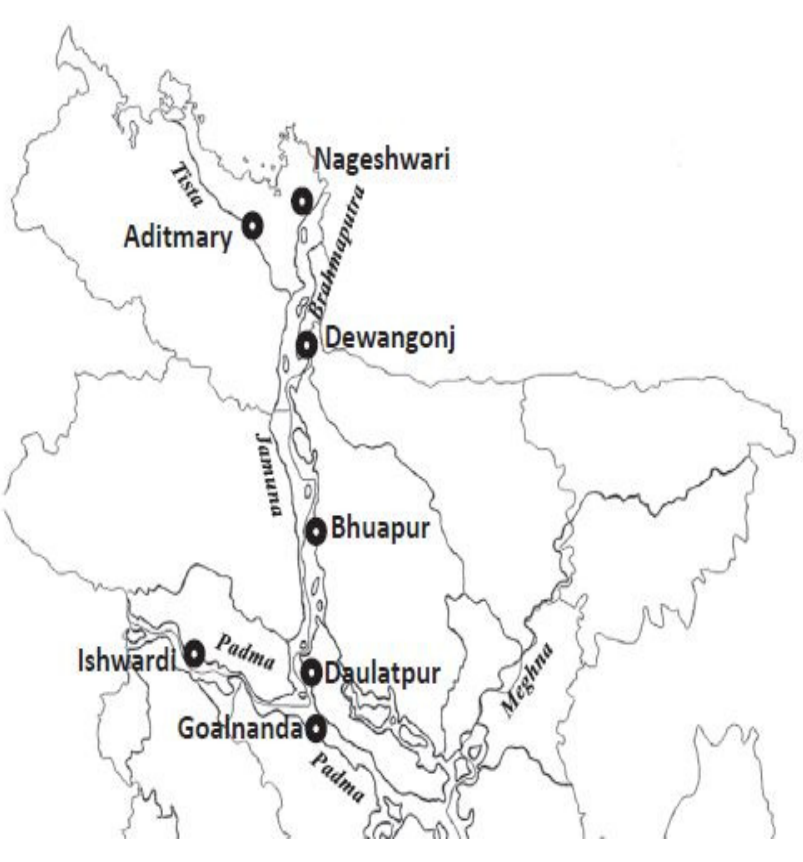

(a)

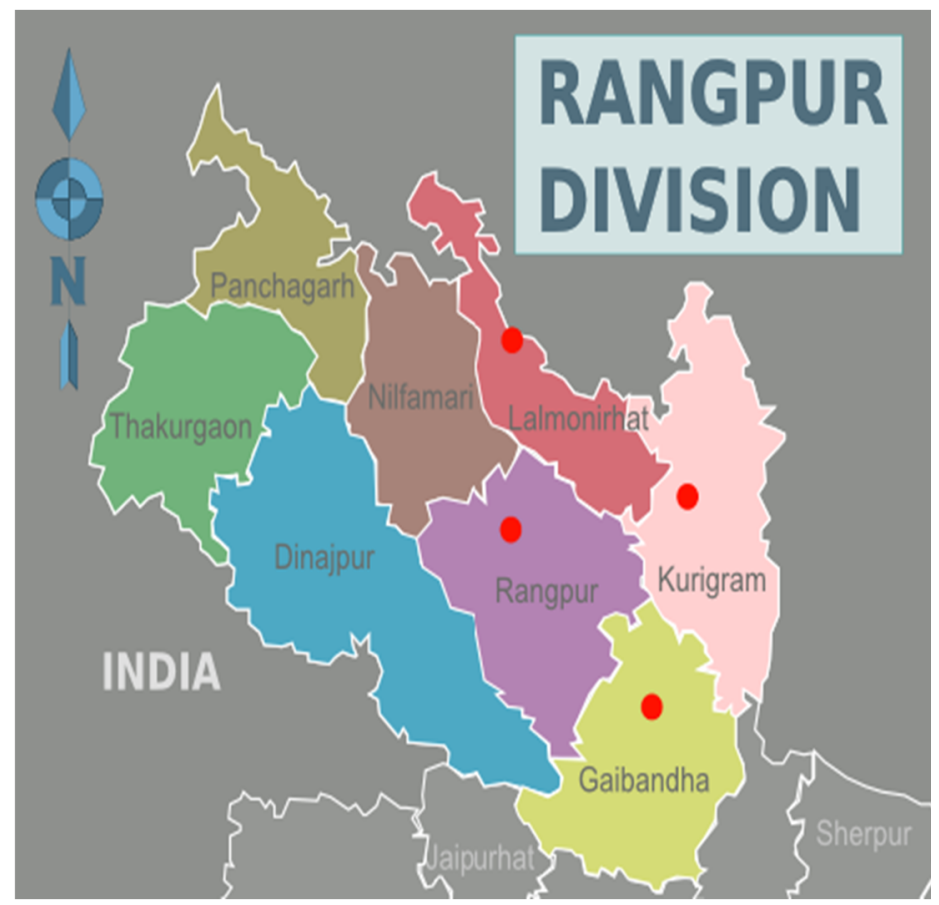

(b)

Figure 1. Location of the study area surrounded by (a) river and (b) district. Source: Karim et al., 2017.

Table 1. Location and areas of char lands developed by the main rivers of the Brahmaputra, the Jamuna, and the Tista of Bangladesh.

\begin{tabular}{|c|c|c|c|}
\hline Chars of the Main Rivers & Districts & Adminstrative Unit & Area (ha) \\
\hline The Brahmaputra, the Jamuna, and the Tista & Gaibandha & Fulchori, Shaghata, Sundorgonj & 27,000 \\
\hline The Tista & Rangpur & Gangachara, Kaunia, Pirgachha & 9400 \\
\hline $\begin{array}{l}\text { The Brahmaputra, the Jamuna, and the Tista, } \\
\text { the Dharala, the Dudhkumar }\end{array}$ & Kurigram & $\begin{array}{l}\text { Rawmari, Chilmari, Rajibpur, } \\
\text { Nageshwari, Rajarhat, Ulipur, } \\
\text { Bhurungamari, Sadar, Phulbari }\end{array}$ & 30,000 \\
\hline The Tista & Lalmonirhat & Sadar, Hatibandha, Aditmari, Kaligonj & 11,000 \\
\hline
\end{tabular}

Source: Author's calculation, 2021.

\subsection{Data Collection}

These areas were preferred for the study because they represent actual char characteristics, are susceptible to natural calamities and have the possibility of improvement of existing cropping patterns. A sum of 950 ( 50 from every administrative unit) farmers were chosen with a purposive random sampling technique. Expert personnel were involved in designing questionnaires to perform Focal Group Discussion (FGD and Key Informant Interview (KII) with farmers. For easy operation of the interviews, the questionnaires were pretested accordingly. The farmers were selected with the assistance of the Department of Agricultural Extension (DAE). The fundamental information regarding crops and cropping pattens, crop production troubles, prospects, and kind of cooperation required for the potential improvement of agriculture in the char lands were included in the questionnaire. The farmers of char areas were selected for FGD. Local and Model farmers, Sub-Assistant Agriculture Officers (SAAO), Agriculture Extension Officers (AEO), Additional Agriculture Officers (AAO), Upazilla Agriculture Officers (UAO), scientists of the National Agricultural Research System (NARS), and workers of Non-Government Organization (NGO) working in the respective chars were interviewed for KII. The approaches of the study are presented in Figure 2. 


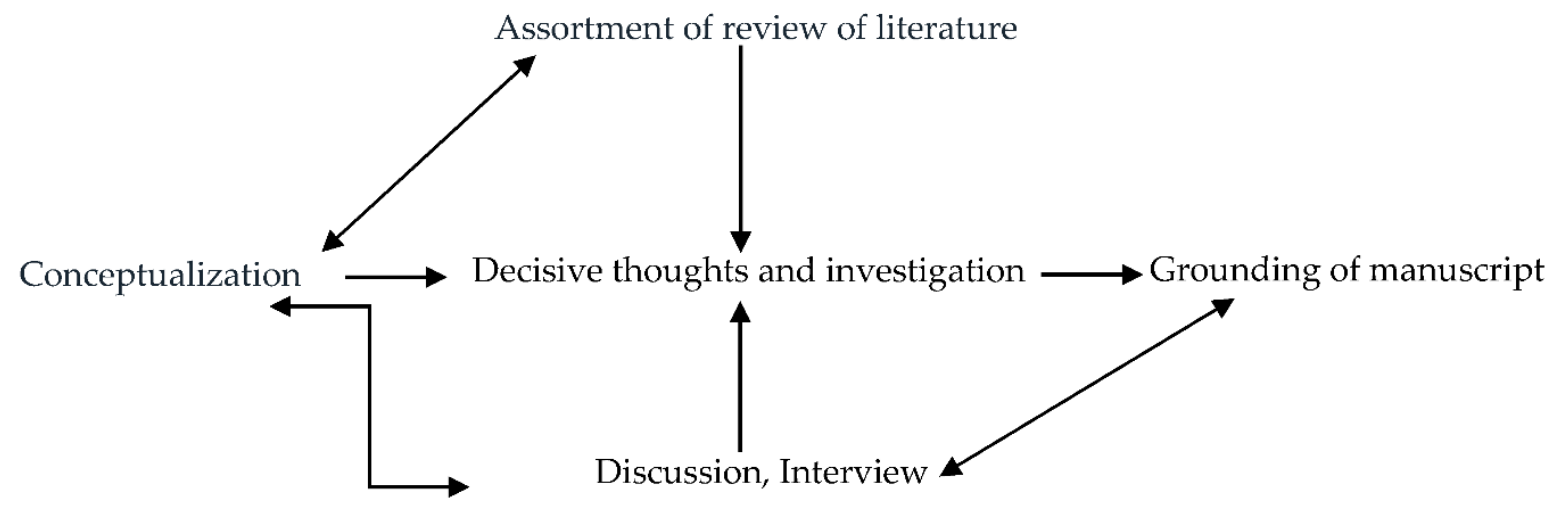

Figure 2. The procedure followed for accomplishment of the study.

\subsection{Data Analysis}

Diverse statistical procedures such as range, mean, number percentage, etc. were utilized to explain the preferred individuality of the farmers of the study area. Microsoft Office Excel 2010 and Statistical Package for Social Science (SPSS version 16.0) were used to analyze the questionnaire records.

\section{Results}

\subsection{Socioeconomic Sketch of the Trial Farmers}

The demographic information of the studied farmers is presented in Table 2. Greater parts of the farmers were in the age of 49.70 to 58.09 years that was measured as most functioning group. Regarding the gender consideration ratio of male and female farmers, the highest male \% (94.22:5.78) was in Lalmonirhat Sadar and the highest female \% (80.45:19.55) was in Chilmari. Educational background was also considered; a large portion of the farmers could make their sign only, and a few percentages completed higher education. The farmers' category was presented in Figure 3. Regarding this character, majorities were landless $(54 \%)$, and large farmers were only $2 \%$. It was originated that the main parts of the trial farmers $(76.11 \%)$ were occupied with crop production and supplementary profit-producing activities like fishing, small business, goat and poultry rearing, daily labor, etc. (Figure 4).

Table 2. Demographic characteristics $(\mathrm{N}=950)$ of the farmers in the study area.

\begin{tabular}{|c|c|c|c|c|c|c|c|c|c|c|c|}
\hline \multirow{2}{*}{ Location } & \multirow{2}{*}{ Participants } & \multicolumn{2}{|c|}{ Gender (\%) } & \multirow{2}{*}{$\begin{array}{l}\text { Average } \\
\text { Age }\end{array}$} & \multicolumn{7}{|c|}{ Education (\%) } \\
\hline & & Male & Female & & Illiterate & Can Sign Only & Primary & Class $\mathrm{X}$ & SSC & HSC & Higher Education \\
\hline Fulchori & 50 & 88.45 & 11.55 & 51.80 & 23.90 & 36.89 & 21.80 & 9.56 & 4.12 & 3.35 & 0.38 \\
\hline Shaghata & 50 & 92.20 & 7.80 & 54.50 & 27.70 & 31.05 & 20.90 & 10.00 & 5.45 & 4.20 & 0.70 \\
\hline Sundorgonj & 50 & 85.30 & 14.70 & 50.50 & 25.50 & 30.60 & 18.80 & 13.60 & 5.50 & 4.50 & 1.50 \\
\hline Gangachara & 50 & 89.50 & 10.50 & 55.80 & 22.30 & 27.70 & 24.60 & 10.00 & 7.90 & 6.50 & 1.00 \\
\hline Kaunia & 50 & 90.00 & 10.00 & 49.70 & 23.33 & 33.43 & 22.67 & 8.87 & 6.80 & 4.00 & 0.90 \\
\hline Pirgachha & 50 & 80.76 & 19.24 & 57.63 & 24.47 & 31.51 & 25.00 & 7.98 & 6.43 & 3.85 & 0.76 \\
\hline Rawmari & 50 & 89.87 & 10.13 & 55.20 & 20.78 & 37.80 & 22.68 & 8.00 & 5.67 & 4.30 & 0.77 \\
\hline Chilmari & 50 & 80.45 & 19.55 & 55.70 & 23.44 & 40.80 & 19.90 & 7.50 & 4.60 & 3.20 & 0.56 \\
\hline Rajibpur & 50 & 84.78 & 15.22 & 57.80 & 24.76 & 34.54 & 22.17 & 8.60 & 5.43 & 4.00 & 0.50 \\
\hline Nageshwari & 50 & 90.65 & 9.35 & 52.90 & 26.90 & 34.76 & 24.30 & 6.25 & 4.11 & 3.13 & 0.55 \\
\hline Rajarhat & 50 & 88.22 & 11.78 & 54.66 & 20.67 & 30.90 & 27.89 & 10.65 & 5.42 & 4.12 & 0.35 \\
\hline Ulipur & 50 & 84.55 & 15.45 & 50.80 & 25.12 & 32.80 & 25.19 & 7.37 & 5.34 & 3.78 & 0.40 \\
\hline Bhurungamari & 50 & 93.23 & 6.77 & 58.09 & 27.87 & 33.55 & 23.45 & 6.78 & 4.90 & 3.04 & 0.41 \\
\hline Kurigram Sadar. & 50 & 90.12 & 9.88 & 53.90 & 22.00 & 35.57 & 25.12 & 8.98 & 4.65 & 3.00 & 0.68 \\
\hline Phulbari & 50 & 87.55 & 12.45 & 55.00 & 19.78 & 37.90 & 26.44 & 6.45 & 5.23 & 3.90 & 0.30 \\
\hline Lalmonirhat Sadar & 50 & 94.22 & 5.78 & 52.98 & 22.43 & 34.47 & 25.14 & 7.12 & 6.34 & 4.10 & 0.40 \\
\hline Hatibandha & 50 & 86.78 & 13.22 & 55.68 & 20.90 & 36.80 & 26.50 & 6.60 & 5.11 & 3.59 & 0.50 \\
\hline Aditmari & 50 & 88.56 & 11.44 & 53.90 & 23.00 & 38.80 & 24.40 & 6.12 & 4.66 & 2.80 & 0.22 \\
\hline Kaligonj & 50 & 85.00 & 15.00 & 56.80 & 25.44 & 33.90 & 23.06 & 7.35 & 6.24 & 3.66 & 0.35 \\
\hline
\end{tabular}




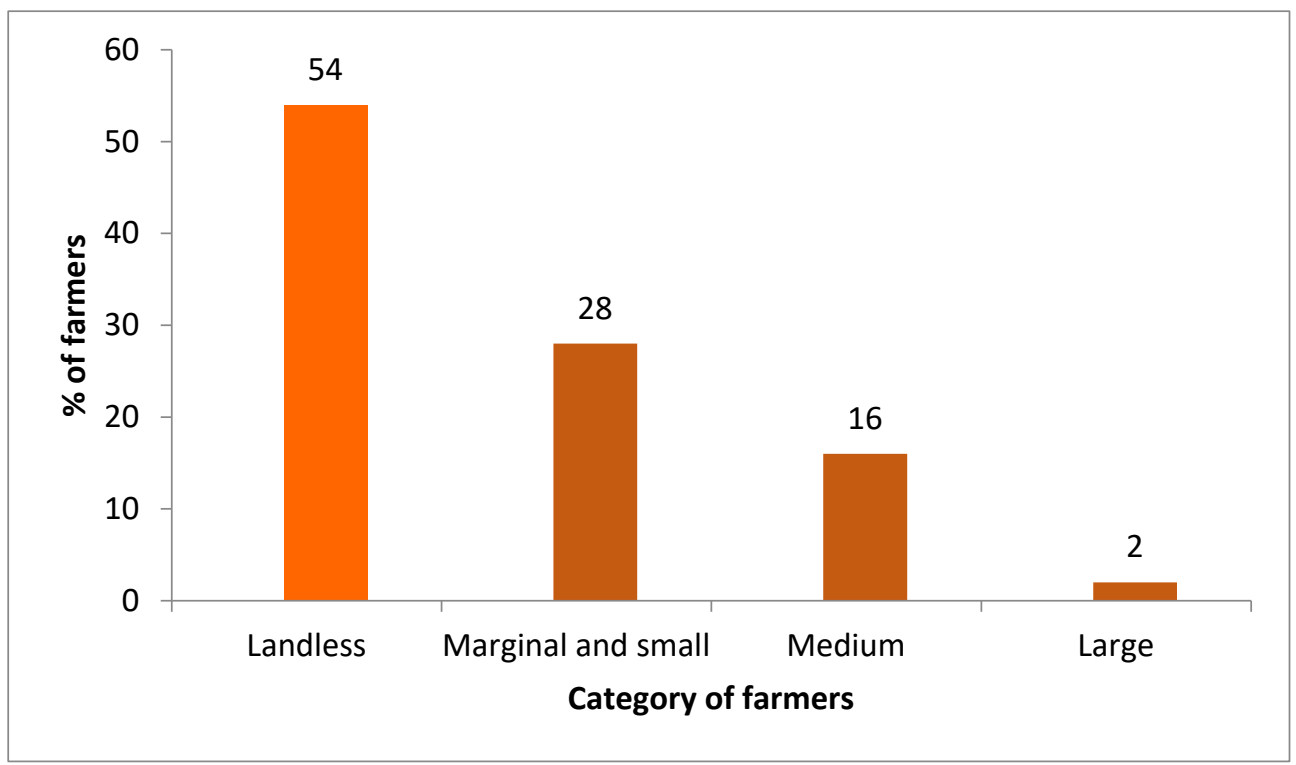

Figure 3. Category of farmers according to their farm size in the study area (Landless up to 0.5 acre; Marginal, 0.51 to 1.0 acres; Small, 1.01 acres to 2.5 acres; Medium, 2.51 acres to 5.0 acres; and Large, 5.01 acres and above).

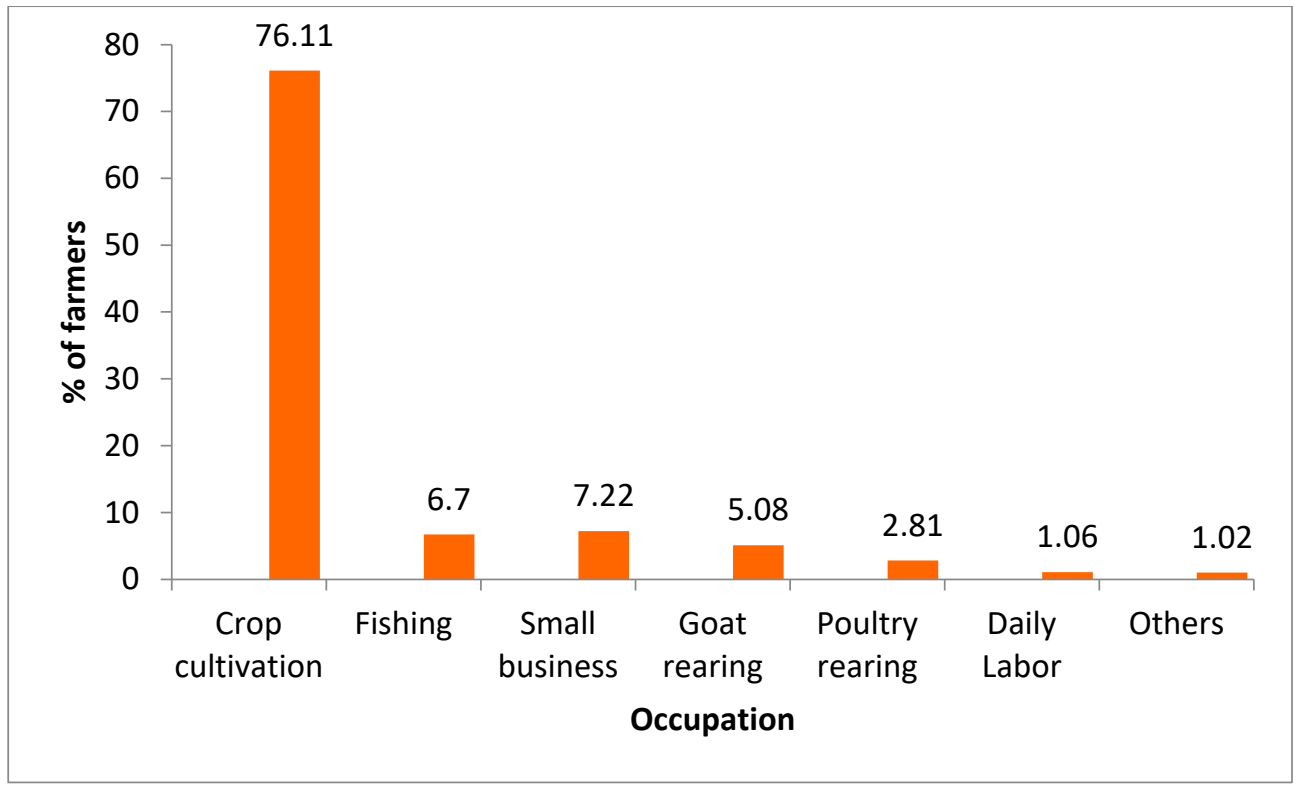

Figure 4. Occupational status of the farmers in the study area.

\subsection{Frequency of Natural Disaster and Its Impact on Production in Char Area}

The farmers of the char areas suffer from usual recurrent calamities like floods, river erosion, nor'westers, cold waves, droughts, hailstorms, and excessive rain from their beginning of life to death. It was observed from Figure 5 that flood was the main disaster $(49.34 \%)$, followed by river erosion $(33.12 \%)$, excessive rain $(5.08 \%)$, drought $(4.21 \%)$, cold wave $(3.21 \%)$, hailstorm $(2.89 \%)$, and nor'wester $(2.15 \%)$. Farmers' thoughts about the changing trend of natural hazards and its effect on crop production were demonstrated in Table 3. About $93.26 \%$ of the farmers opined that natural disasters occurred more frequently than in previous times. Similarly, $52.94 \%$ of farmers strongly agreed that crop production was affected with the increasing frequency of natural calamities. 


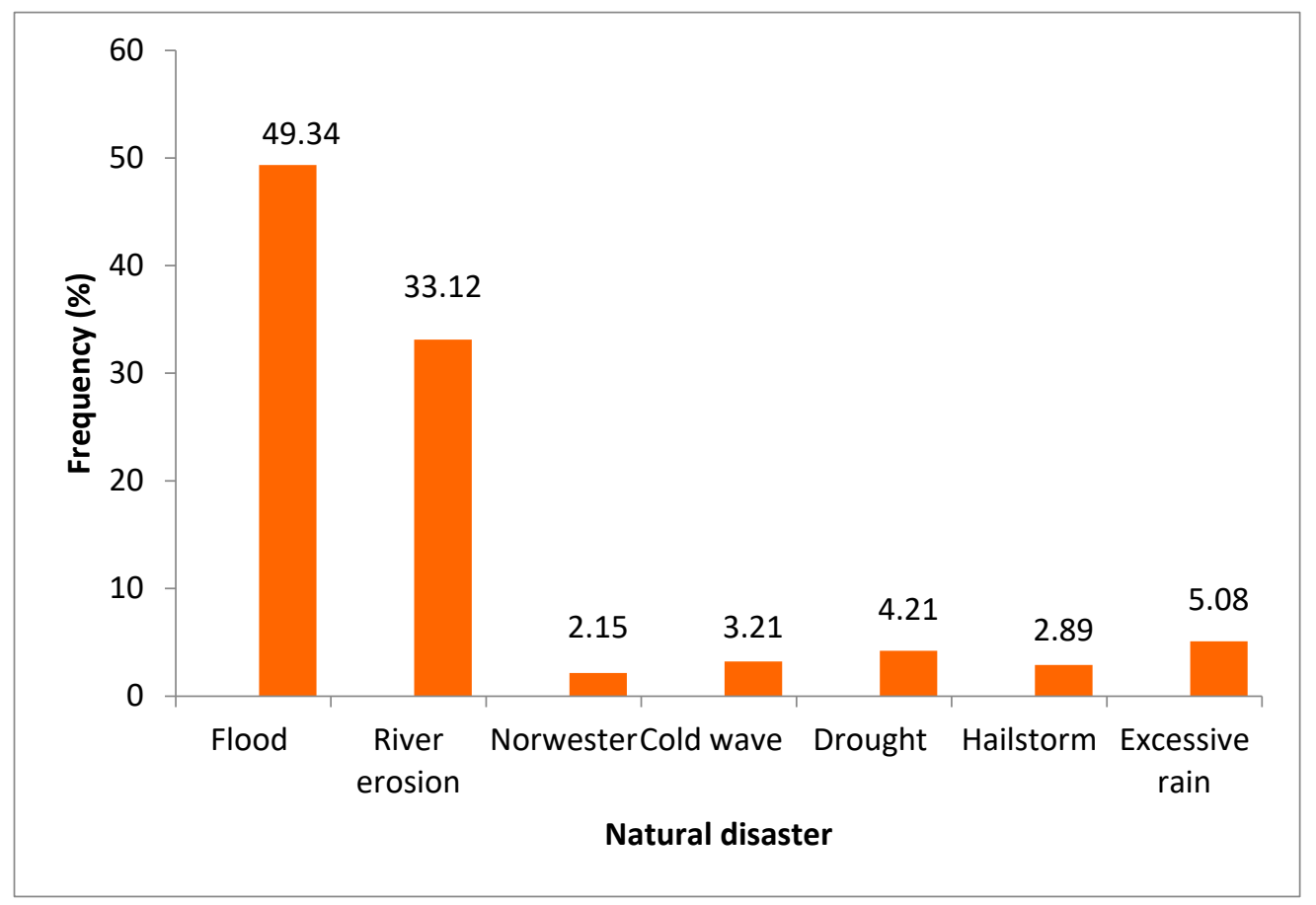

Figure 5. Intensity of natural disaster in the study area.

Table 3. Farmers' attitude towards changing trend of natural hazards and its impact on crop production.

\begin{tabular}{cccccccc}
\hline & \multicolumn{3}{c}{ Natural Hazard } & \multicolumn{3}{c}{ Effect on Crop Production } \\
\hline & Frequency & Percentage & Cumulative Percentage & & Frequency & Percentage Cumulative Percentage \\
\hline Do not know & 11 & 1.16 & 1.16 & Neutral & 5 & 0.53 & 0.53 \\
Yes & 886 & 93.26 & 94.42 & Agree & 442 & 46.53 & 47.06 \\
No & 53 & 5.58 & 100 & Strongly & 503 & 52.94 & 100 \\
Total & 950 & 100 & & agree & 950 & 100 & \\
\hline
\end{tabular}

\subsection{Problem Associated with Crop Production in Char Area}

The main problems related to crop production were recognized by FGD and KII (Table 4). The transmission procedure of improved variety and techniques developed by different agricultural research organizations was relatively slow as the chars were situated in isolated parts. Moreover, the farmers were not conscious of new varieties and methods in the recent times. It is difficult to keep quality seed produced by farmers due to a lack of technical knowledge and proper preservation methods. Furthermore, the superiority of their own seeds declined as a result of regular flooding. The farmers had a restriction to purchase quality seed from the market due to poor communication. In this case, the local dealers are the main source of collecting seed, and they sometimes commit fraud. The soils were somewhat sandy in most of the char area, thus crops require significant irrigation. Besides, there was a problem of adequate irrigation facility in the chars. Due to lack of electricity, the irrigation pumps were operated by diesel, and it was more costly for poor farmers. 
Table 4. The main limitations of crop production in the selected char areas of Bangladesh.

\begin{tabular}{|c|c|c|}
\hline Core Problems & Connecting Problems & Source of Information \\
\hline \multirow{2}{*}{ Delay in technology dissemination } & $\begin{array}{l}\text { Farmers were not well aware of high yielding } \\
\text { crops and techniques appropriate for char area. }\end{array}$ & Model farmer of Hatibandha \\
\hline & $\begin{array}{l}\text { Farmers were not conscious of current farming } \\
\text { practices and post-harvest supervision of crops. }\end{array}$ & $\begin{array}{l}\text { Agriculture Extension Officer (AEO) } \\
\text { of Gangachara }\end{array}$ \\
\hline \multirow{3}{*}{ Unavailability of quality seed in time } & $\begin{array}{l}\text { Farmers did not have enough information on } \\
\text { crop production and conservation of quality } \\
\text { seeds by their own capacity. }\end{array}$ & Model farmer of Aditmari \\
\hline & $\begin{array}{c}\text { Proper storage ability was not accessible in } \\
\text { the char. }\end{array}$ & $\begin{array}{l}\text { Upazila Agriculture Officer (UAO) } \\
\text { of Sundorgonj }\end{array}$ \\
\hline & $\begin{array}{l}\text { Defilement of seeds was found when collected } \\
\text { from the local market. }\end{array}$ & $\begin{array}{l}\text { Sub Assistant Agriculture Officer } \\
\text { (SAAO) of Shaghata }\end{array}$ \\
\hline \multirow{4}{*}{$\begin{array}{l}\text { Fertilizers and manures are not } \\
\text { gladly available }\end{array}$} & $\begin{array}{l}\text { Local dealers are the main supplier of fertilizers } \\
\text { and manures who sometimes cheat with farmers. }\end{array}$ & $\begin{array}{l}\text { Sub Assistant Agriculture Officer } \\
\text { (SAAO) of Ulipur }\end{array}$ \\
\hline & $\begin{array}{l}\text { Not enough storage capability for storing the } \\
\text { fertilizer for a significant time. }\end{array}$ & $\begin{array}{c}\text { Additional Agriculture Officer (AAO) } \\
\text { of Sundorgonj }\end{array}$ \\
\hline & Occasionally ruination of fertilizer was observed. & $\begin{array}{l}\text { Scientist, Bangladesh Agricultural } \\
\text { Research Institute (BARI), Rangpur }\end{array}$ \\
\hline & $\begin{array}{c}\text { Farmers do not use micronutrients like } \mathrm{Zn}, \mathrm{B}, \mathrm{Ca} \text {, } \\
\text { and } \mathrm{Mg} \text { for growing crops due to lack } \\
\text { of awareness. }\end{array}$ & Local Dealer of Kaunia \\
\hline \multirow{3}{*}{ Deficit in sufficient irrigation ability } & $\begin{array}{c}\text { There was no electricity supply in remote char } \\
\text { area, and diesel cost is higher for running } \\
\text { irrigation pump. }\end{array}$ & $\begin{array}{l}\text { Sub Assistant Agriculture Officer } \\
\text { (SAAO) of Fulchori }\end{array}$ \\
\hline & $\begin{array}{l}\text { Insufficient quantity of irrigation pumps } \\
\text { contrasted to the demand. }\end{array}$ & $\begin{array}{c}\text { Upazila Agriculture Officer (UAO) } \\
\text { of Ulipur }\end{array}$ \\
\hline & $\begin{array}{l}\text { Minimum water holding capacity in sandy soil, } \\
\text { thus numerous irrigations were required. }\end{array}$ & Model farmer of Kaligonj \\
\hline \multirow{4}{*}{ Short in eminence pesticides } & $\begin{array}{l}\text { Farmers collect pesticides from dealers in the } \\
\text { local market and far away from char lands. }\end{array}$ & $\begin{array}{l}\text { Sub Assistant Agriculture Officer } \\
\text { (SAAO) of Hatibandha }\end{array}$ \\
\hline & $\begin{array}{l}\text { Farmers have no knowledge on typical } \\
\text { pesticides and their dosages. }\end{array}$ & Local Dealer of Aditmari \\
\hline & $\begin{array}{l}\text { Service contributors were not accessible } \\
\text { when required. }\end{array}$ & Model farmer of Phulbari \\
\hline & $\begin{array}{l}\text { Some farmers were disinclined to purchase } \\
\text { pesticides due to corruption. }\end{array}$ & Model farmer of Kaligonj \\
\hline \multirow[t]{2}{*}{ Problems of preservation facility } & $\begin{array}{l}\text { Deficiency of appropriate storage space and } \\
\text { post-harvest processing of locally } \\
\text { produced product. }\end{array}$ & Local farmer of Lalmonirhat Sadar \\
\hline & $\begin{array}{l}\text { Farmers sold their goods just after harvesting at } \\
\text { inferior price because of lack of storage ability. }\end{array}$ & Local farmer of Ulipur \\
\hline \multirow{2}{*}{ Constraints in marketing of product } & $\begin{array}{l}\text { Poor communication and transportation between } \\
\text { chars and wholesale market. }\end{array}$ & $\begin{array}{l}\text { Sub Assistant Agriculture Officer } \\
\text { (SAAO) of Kaligonj }\end{array}$ \\
\hline & $\begin{array}{l}\text { Farmers were not getting a good value of their } \\
\text { product due to lack of market facility. }\end{array}$ & District Marketing Officer of Rangpur \\
\hline Unavailability of credit & $\begin{array}{l}\text { Inadequate loan support from } \\
\text { credit organization. }\end{array}$ & Local farmer of Rajibpur \\
\hline
\end{tabular}




\subsection{Sustainable Farming Practiced by Farmers in the Char Areas}

The sustainable farming practices adopted by char farmers are demonstrated in Table 5 . The char dwellers mainly depend on agriculture and agriculture-related activities for their livelihood. Chances of off-farm actions are insignificant. Cultivated crops and homesteads are frequently spoiled due to river erosion. The facilities concerning health, sanitation and environment were at the lowest level. The livelihood pattern of char people is indecisive and susceptible due to natural disasters. There is a necessity to ensure food in a vulnerable situation to maintain their lives. Special importance is needed for the landless and marginal people of char areas, as they do not have land for food production and to meet their own needs.

Table 5. The philosophy of sustainable farming practices and used practice by farmers of char area.

\begin{tabular}{|c|c|}
\hline Sustainable Farming Methods or Practices & Used Practice by Farmers \\
\hline $\begin{array}{l}\text { Renewable power resource e.g., } \\
\text { utilization of solar panels, } \\
\text { hydropower from wind } \\
\text { using water of the river as hydroelectric power }\end{array}$ & $\begin{array}{l}\text { Farmers have no knowledge or even scope on the use of alternate energy } \\
\text { sources such as solar panels, although a few large farmers use this. They } \\
\text { never use running river water as hydroelectric power. } \\
\text { Some large farmers use solar panel systems as a source of electricity in } \\
\text { their household supply. }\end{array}$ \\
\hline $\begin{array}{l}\text { Integrated pest management } \\
\text { cultural control } \\
\text { mechanical control } \\
\text { chemical control } \\
\text { biological control } \\
\text { Supporting agent: } \\
\text { Extension Agent Visit, Farmers Field School, IPM Club }\end{array}$ & $\begin{array}{l}\text { Farmers cultivate crops and vegetables, and they usually utilize } \\
\text { chemical control. } \\
\text { They use chemicals based on their knowledge and sometimes based on } \\
\text { the experience of local dealers. } \\
\text { Some model farmers are involved with farmers' field schools and IPM } \\
\text { clubs and trained about the basic concept of IPM. }\end{array}$ \\
\hline
\end{tabular}

\section{Crop rotation}

nutrient steadiness

reasonable soil health

shallow-rooted crop cultivation after deep-rooted crop

exhaustive crop followed by restorative crop

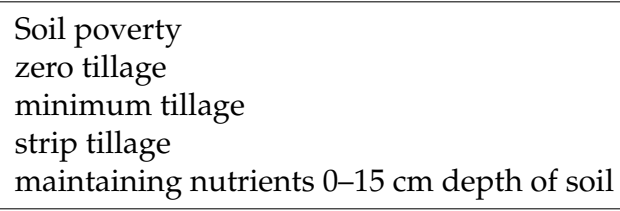

\section{Crop multiplicity}

terrestrial diversity

freshwater assortment
The char people are not well aware of crop rotation.

They grow crops sporadically based on their own needs and market demand.

Small farm holding is a major problem for practicing crop rotation.
Farmers use power tiller or plough for cultivating land that enhances soil degradation. Farmers rarely practice minimum tillage to grow groundnut, cucumber, etc. Sometimes soil erosion is beyond control due to strong wind blow.
The cropping patterns are mainly rice-based.

Pulse crops are neglected in char areas.

Oilseed crops and vegetables are cultivated to meet famers' needs and local demand.
Natural pest control

bats, birds, insects, etc. as natural pest eliminators rearing honeybee and ladybird beetle

\section{Managed grazing \\ continuous grazing \\ rotational grazing}

Famers' practice piercing system mainly in rice field monitored by Department of Agricultural Extension (DAE).

Ladybugs, beetles, green lacewing larvae, and fly parasites naturally feed on pests, including aphids, mites, and pest flies.

There are some grazing lands in the char area. An intermittent shift of the grazing lands for cattle is maintained.

Moving livestock offers them a variety of grazing pastures. They receive a range of nutrients which is good for them.

The excreta of these animals serve as a natural fertilizer for the land.

The marketing system of char area for agricultural products is not developed. The small traders sometimes collect the farmers' products directly from their fields.

Output Market

producer

customer

communication
Sometimes farmers sell their products in the local market. The sale of the production in the local market saves transportation and packaging hassles, although price is comparatively lower and eliminates the need for storage space. 
Table 5. Cont.

\begin{tabular}{|c|c|}
\hline Sustainable Farming Methods or Practices & Used Practice by Farmers \\
\hline $\begin{array}{l}\text { Waste management } \\
\text { composting } \\
\text { disposal recycling }\end{array}$ & $\begin{array}{l}\text { The char farmers are practicing this in their own homestead. } \\
\text { This is normally transformed into fertilizers that can help enrich the soil. }\end{array}$ \\
\hline $\begin{array}{l}\text { Water management } \\
\text { Rainwater harvesting } \\
\text { Watershed management }\end{array}$ & $\begin{array}{l}\text { Farmers of the char area mainly use river water or shallow pump for } \\
\text { their irrigation purpose. } \\
\text { They have no idea about water storage during monsoon and use of this } \\
\text { during drought conditions. }\end{array}$ \\
\hline
\end{tabular}

\subsection{Location-Specific Findings on the Cropping Patterns}

The most practiced cropping pattern in the char areas is T. Aman-Maize-Jute (Table A1). Farmers cultivated T. Aman rice in Kharif II (July-November/December) season in the medium-high and medium-low lands even though there was a threat for damage of the crop due to flood. In the medium-high land, most of the patterns had at least one fallow period, though three crops were also observed to grow in a few patterns. The quantity of crops in Rabi season (dry period; November-March) was much more than that in Kharif I (April-June) or Kharif II (July-October) season. The most practiced cropping pattern of Bangladesh (T. Aman-Fallow-Boro) is a less proficient cropping pattern in the char lands of Bangladesh owing to deficiency of irrigation facilities. There is an enormous capacity of the development of Fallow-Groundnut-Fallow cropping pattern. T. Aman can be cultivated before Groundnut and behind harvest of Groundnut. Jute can be grown without difficulty at the middle portion of char areas. T. Aman and Jute can be cultivated at lower assets and higher profits.

Boro rice-based cropping patterns are more common in Gaibandha district than in Kurigram (Table A2). The T. Aman-Fallow-Boro cropping pattern can be enhanced by adding high yielding varieties of mustard (BARI sarisha-14, BARI sarisha-15). There are so many cropping patterns, but all entirely depend on the moment and severity of flood. The flood frequently destroys chars, and the permanence of chars depends on the course and the intensity of the floodwater.

T. Aman-Maize-Fallow is the most important cropping pattern here, but this can be easily replaced by T. Aman-Maize-Groundnut (Table A3). This will increase cropping intensity. Boro rice is completely absent here. Boro can be cultivated simply by improving irrigation facilities to boost overall production. In the chars, the farmers widely produce local rice varieties. The conventional varieties are tall-statured, photosensitive, and flower under short-day conditions, and yield is inferior. Thus, there is a vast scope of introducing high-yielding varieties.

A number of cropping patterns were subsisted in every char. Seventeen cropping patterns were composed of crops in the three seasons out of the twenty patterns (Table A4). The cropping pattern, including T. Aman rice, consisted of three crops. This is an excellent indication of supplementary cropping intensity. Lalmonirhat Sadar encompasses more cropping patterns than other administrative units. Tobacco is specially cultivated in the Tista char of Aditmari. As natural disaster is very frequent in char areas, homestead gardening is favored for supplementation mainly vegetables and spices in disaster period. Besides, farmers can grow short-duration vegetables in the fallow land near their homesteads to meet regular demand and sell at a higher price. Another significant factor is to practice growing all crops a bit earlier in the climax season to obtain more prices in the market.

\subsection{Major Cropping Pattern, Diseases and Pest in the Study Area}

A number of cropping patterns existed in the study areas, and the major cropping patterns were T. Aman-Maize-Jute, T. Aman-Potato-Groundnut and T. Aman-Potato-Fallow. It is evident from Figure 6 that farmers were engaged in T. Aman-Maize-Jute cultivation in Sadar, Fulchori, Shaghata, and Sundarganj administrative units of Gaibandha district where 
T. Aman-Maize-Fallow was practiced in Sadar, Aditmari, and Kaliganj administrative units of Lalmonirhat district. Important diseases and pest attacks were enlisted in the study area. The most severe disease was late blight in potato (65.19\%) (Figure 7), whereas yellow stem borer and brown plant hopper (56.8\%) was the dominant pest in rice (Figure 8 ).

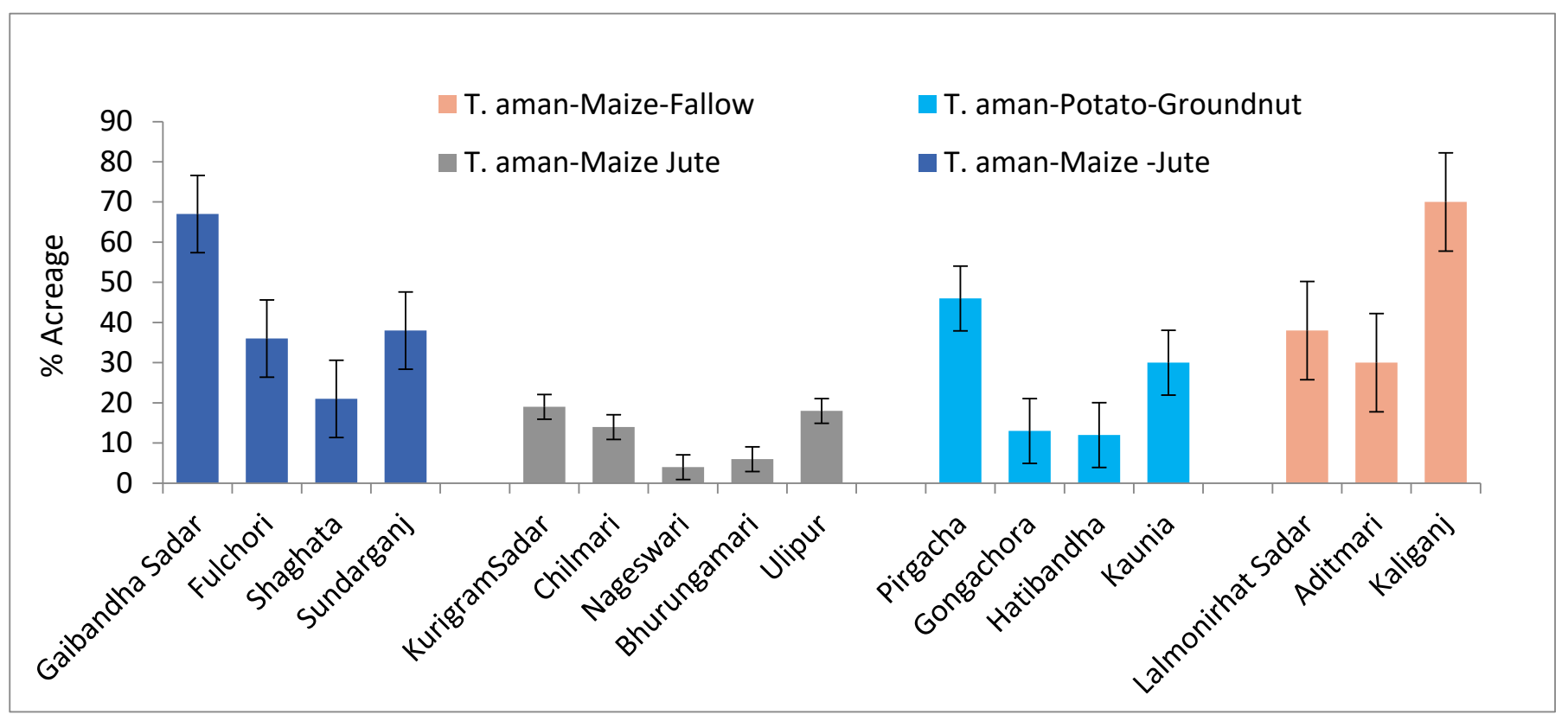

Figure 6. Location wise major cropping patterns in the study area. Vertical bars are standard errors of means.

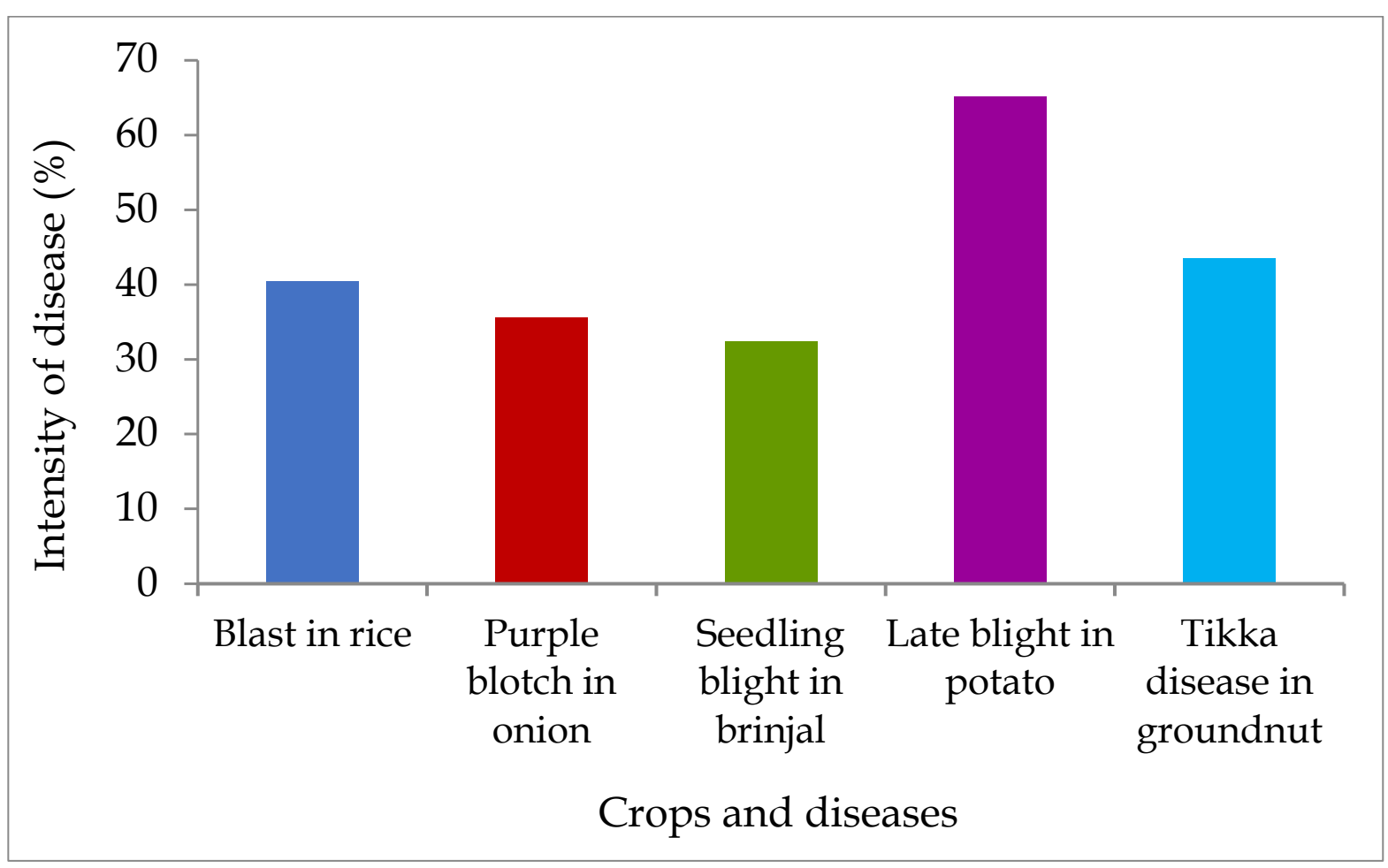

Figure 7. Intensity of major diseases of main crops in the study area. 


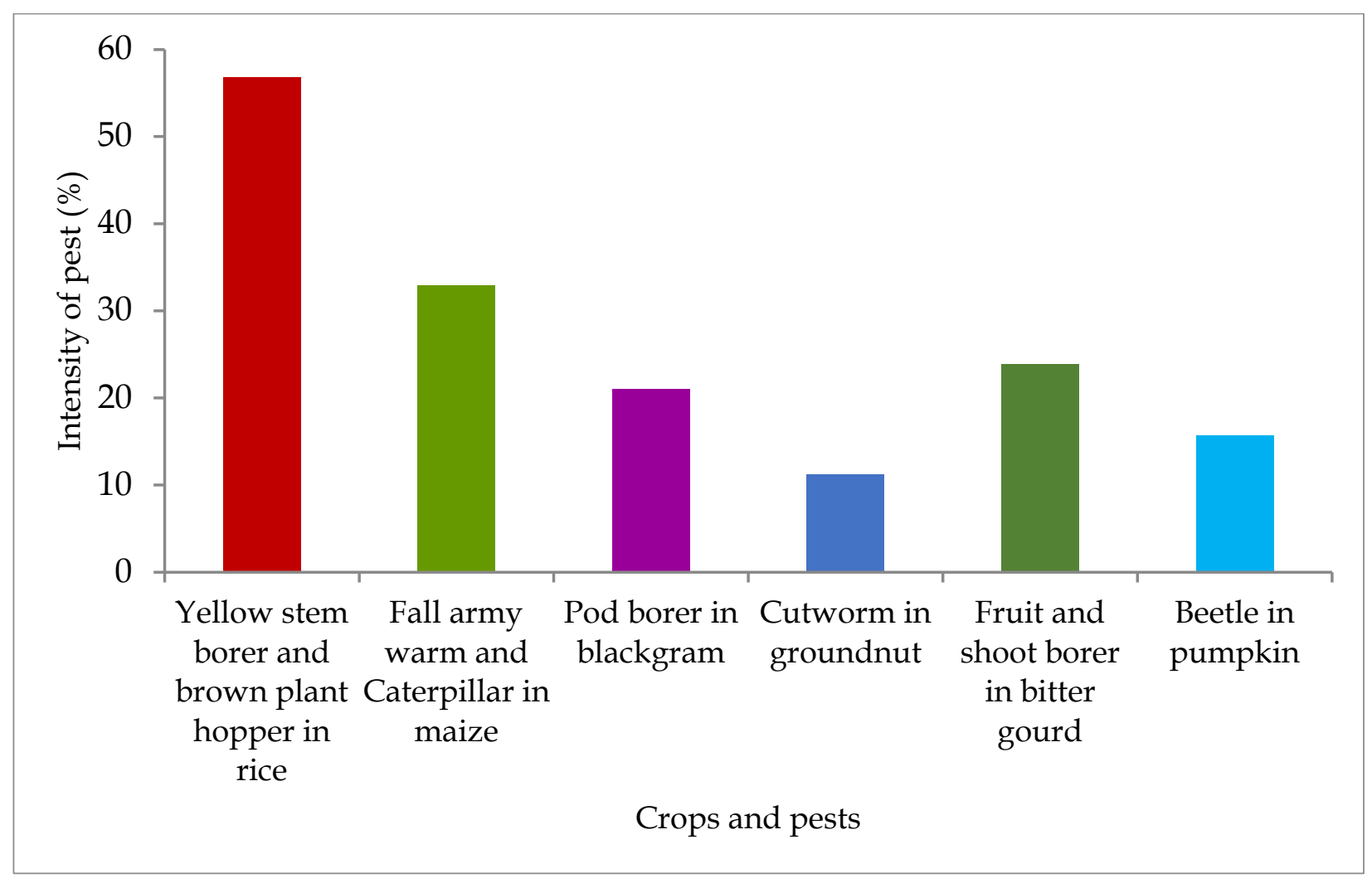

Figure 8. Intensity of major pests of main crops in the study area.

\section{Discussion}

In this study, we have explored socio-economic information, occupation, crop production problem, sustainable practices used by char farmers, cropping pattern scenario based on land area, farmers' choice, and market facilities of four districts of char area of Bangladesh. The agricultural land of Bangladesh is decreasing at a rate of 0.73 percent per annum due to different developmental activities, particularly infrastructure expansion, and it is an immensely distressing situation for increasing agricultural productivity of the country [15]. The agricultural production is rising considerably throughout the country, even though there has been a declining trend of land areas for the last three decades. The advanced agricultural production in the char area can enhance countrywide crop production. Furthermore, it can donate to a large extent in order to attain national food security. The char lands have been created as a result of accumulation of Himalayan sediments along with the cache of the large rivers [16]. The soil category, type of crops grown, and problems associated with agricultural production depend significantly on the rivers and position of the chars, as the isolated riverbeds of various rivers produce these lands.

The study pointed out that the chars were still located in the extremely isolated areas. Additionally, the average age of the farmers ranged from 49.70 years in Kaunia to 58.09 years in Bhurungamari. The usual age of the farmers in various chars was much related to that of mainlands-43 years in Gazipur District [17] and 49 years was in Chandpur District [18]. It was established that most farmers are not well educated, but it was a good indicator for attaining knowledge to ensure food security [11].

Natural hazards deprived char farmers in Bangladesh due to their frequency and significant loss $[2,6,19,20]$. Natural disaster is the incidence of an irregular or sporadic hazard that has an impact on helpless communities, such as people of char areas, and cause considerable harm, disturbance, and probable losses, and parting the exaggerated society not capable to task in general. From a financial viewpoint, a disaster involves some mixture of fatalities in terms of personal, physical, and financial capital and a decrease in 
monetary actions [21]. In char areas, floods frequently destroy chars, and the durability of chars depends on the time duration and the strength of the floodwater. Sometimes, the amount of rain in the Himalayas is excessive enough that the entirety of the crops grown in the chars must be bulldozed. The flood spoils crops, frequently aman rice and, in some cases, jute and delayed sown aus rice. The length of flood in the chars is also doubtful. Occasionally, at the time of depression of flood water, an additional new-fangled flood (double flood) took place as a result of unexpected rains in the Himalayas. Although farmers knew that they might drop their crops in summer, having no options for food security, they still cultivate T. aman in the medium lands. The crops and cropping are assorted mainly due to flooding patterns and land category [10]. In reaction to the existing climate change risks, the char people utilize a number of adaptation strategies in agriculture, such as implementing new or alternative farming practices, changing planting times, and cultivating short-duration varieties [22,23].

T. Aman-Maize-Jute is the most widespread cropping pattern, and T. Aman is cultivated with most of the cropping pattern in char areas. Major cropping patterns were rice-based in char area [9]. T. Aman covered the largest part of the cropping area (53\%) of the net cropped area (NCA) in Rangpur region [24]. Famers transplant T. Aman rice haphazardly, maintaining no planting density. Farmers of char areas cultivate wheat in rainfed conditions. The soil of the char area is suitable for potato cultivation and sometimes farmers cultivate two times in the same season, but they are reluctant to use fungicide control disease in potato. They consider groundnut as a low-value crop. Therefore, they use the minimum amount of fertilizer, organic manure, and crop protection measures like fungicides and insecticides to protect plants from diseases and insects. They directly sell groundnut after harvest at low cost due to lack of storage facilities. There are very few shelling machines available in chars for maize cultivation that can serve only a small number of farmers. Moreover, the unavailability of high yielding varieties (HYV) of mustard seeds forces char farmers to use local variety such as Tori-7. They do not use irrigation and cultivate this crop in rainfed conditions. Farmers of the char area only grow onion in the Rabi (October-March) season. Farmers usually sow jute in late to avoid irrigation and wait for rain. Farmers use traditional retting techniques that cause damages to the fibre. Farmers followed the broadcasting method for sowing black gram seeds in all areas.

In spite of various cropping patterns that were originated in each char, three crops were quite inadequate as a result of the unavailability of medium high land. Most of the patterns consisted of one or two crops. Thus, the cropping intensity and yields ha ${ }^{-1}$ were stumpy in the majority of the chars of the studied regions. However, crop productivity and cropping intensity can be accelerated by practicing an improved cropping pattern (Wheat- Jute-T. Aman) in Netrakona region of Bangladesh [8]. The slow dissemination of high yielding varieties and recent technologies to the char farmers resulted in lower crop productivity. The utilization of local varieties by the farmers was reasoned by the unavailability of seeds, higher value of the quality seeds, high fertilizer necessity, and unhurried distribution of technology and unavailability of funds for the poor farmers. The Kharif I (pre-monsoon) season is differentiated by little precipitation, less soil moisture, elevated temperature, and soaring requirement for evapotranspiration. The sand subjugated char soils suffered from sufficient water holding capacity and water scarcity as a result of insufficient or no rainfall in the pre-monsoon period. In that situation, the char farmers habitually cultivate aus rice, jute, and sesame. The efficiency of this cropping season was rather low contrasted to Rabi (dry season) and Kharif II seasons (summer; monsoon) in char areas. The plants are faced with adverse situations, especially for the post-monsoon drought environment. In such conditions, the farmers exercise long seedlings transplanting practice to escape drought [25]. Still, there was irrigation ability in several places; the lofty diesel cost made the irrigation cost excessive. Furthermore, low yield at Kharif I season and insecurity in receiving reasonable value of the manufactured goods made the farmers unenthusiastic to devote to their Kharif I crop production. As a result, Kharif I period crops were generally rainfed in all the chars. 
Sustainable farming is by means of farming practices in view of the ecological phases. In simple form, sustainable farming is utilizing agricultural practices ecologically by supporting techniques and practices that are economically feasible, environmentally safe, and that guard public health. Though farmers of char area are involved some sustainable practices, due to some critical problems such as unavailability of up-to-date information and poor communication systems hindering sustainable national agricultural productivity. On the other hand, due to hard communication structure, the farmers had to pay more money for the input assortment from the mainland marketplace but obtain lower prices of their product due to elevated carrying cost. Input grant, output value support, and social security net plans organized by the government can be a good option to shelter the char dwellers in emergency period and increase their living situation [10]. Due to lack of electricity, farmers had to buy diesel at higher cost for managing their irrigation pumps. In addition, the farmers failed to collect proper inputs timely due to lack of credit supply in time. The agricultural production in the char lands is predicted to boost up considerably if those troubles could be reduced to some extent. Still, the agricultural troubles in the char lands are multidimensional, inclusive actions such as up-to-date crop production technologies, humanizing extension service connection, and accommodating of the farmers are necessary from production to marketing of their produces to solve these troubles.

\section{Conclusions}

The involvement of char land agriculture can play a vital role in the productivity of the national agricultural system of Bangladesh. In a condition where agricultural land is declining frighteningly in the mainland, it is essential to boost crop productivity with supplementary augmentation of char regions. The results showed that the majority of farmers were landless. Among different occupations, crop cultivation takes up a major portion compared to other professional indicators. Flood is the most dominant hazard among natural disasters. Binadhan-7 (short duration variety) may be cultivated to avoid flash floods. Late blight of potato is a serious disease, and chemical control is the best measure. Farmers are indicated to use proper fungicide (Ridomil Gold) to control the late blight of potato ahead of the disease appearing. Seed treatment with boric acid (3\%) is also very important to minimize the soil borne fungus attacks. Yellow stem borer and brown plant hopper are the foremost pests in the study area, which can be controlled by systemic pesticides. Purple blotch is also a serious disease that can be controlled by joint application of Rovral and Ridomil. Proper storage of onion with sand can increase the farmers' income in offseason. Despite these major findings, the other troubles associated with technology dissemination, inputs and credit accessibility, storage space, irrigation ability, structured marketing system, etc. can be reduced by undertaking effective and inclusive programs for more development of the farming productivity and financial circumstances of the char farmers. The outcome of this study based on interviews and discussion will support researchers, contributors, and policymakers to establish an agricultural plan towards attaining sustainable farming practice.

Author Contributions: Conceptualization: U.K.S., M.S.K. and M.R.U. Methodology, data collection, and original data analysis: U.K.S. and M.R.U. Data presentation, writing: U.K.S.; reviewing and editing: M.R.U., M.A.H. and S.H. Funding acquisition: S.H. and M.M.H. All authors have read and agreed to the published version of the manuscript.

Funding: This research was funded by Swiss Contact Project and Taif University Researchers Supporting Project number (TURSP-2020/142), Taif university, Taif, Saudi Arabia.

Institutional Review Board Statement: Not applicable.

Informed Consent Statement: Not applicable.

Data Availability Statement: Data sets analyzed during the current study are available from the current author on reasonable request. 
Acknowledgments: The authors extend their appreciation to Swiss Contact Project Authority and Taif University for funding current work by Taif University Researchers Supporting Project number (TURSP-2020/142), Taif University, Taif, Saudi Arabia.

Conflicts of Interest: The authors declare no conflict of interest.

\section{Appendix A}

Table A1. Cropping Pattern practiced in different administrative unit of Gaibandha district.

\begin{tabular}{|c|c|c|c|c|}
\hline \multirow{3}{*}{ Cropping Pattern } & \multicolumn{4}{|c|}{ Different Administrative Unit of Gaibanda } \\
\hline & GaibandhaSadar & Fulchor & Shaghata & Sundarganj \\
\hline & \multicolumn{4}{|c|}{$\%$ Acreage } \\
\hline T. aman-Maize-Jute & 67 & 36 & 21 & 38 \\
\hline Fallow-Chili (Red)- Jute & - & 29 & 21 & - \\
\hline $\mathrm{T}$ aman-Mustard-Boro & - & 9 & - & - \\
\hline T. aman-Fallow-Boro & 11 & 5 & - & 14 \\
\hline Fallow-Groundnut-Fallow & 9 & 5 & 4 & - \\
\hline Fallow-Maize -Jute & - & 4 & 28 & - \\
\hline T. aman-Wheat- Jute & - & - & 16 & 21 \\
\hline Fallow-Ground Nut-Sesame & - & - & - & 9 \\
\hline T. aman-Potato- Jute & - & - & - & 7 \\
\hline Fallow-Boro-Fallow & - & - & - & 5 \\
\hline T. aman-Maize-Fallow & - & - & - & 3 \\
\hline Fallow-Onion-Kaun & - & - & 4 & - \\
\hline Fallow-Ground nut -Cheena & - & 3 & - & - \\
\hline Fallow-Ground nut-Kaun & & 3 & - & - \\
\hline Fallow-Onion-Fallow & - & 2 & - & 3 \\
\hline T. aman-Boro Jute & 7 & - & - & - \\
\hline
\end{tabular}

Table A2. Cropping Pattern practiced in different administrative unitof Kurigram district.

\begin{tabular}{|c|c|c|c|c|c|}
\hline \multirow{3}{*}{ Cropping Pattern } & \multicolumn{5}{|c|}{ Different Administrative Unit of Kurigram } \\
\hline & KurigramSadar & Chilmari & Nageswari & Bhurungamari & Ulipur \\
\hline & \multicolumn{5}{|c|}{$\%$ Acreage } \\
\hline T. aman-Maize Jute & 19 & 14 & 4 & 6 & 18 \\
\hline T. aman-Wheat- Jute & - & 19 & 18 & 40 & 6 \\
\hline Fallow-Boro-Fallow & - & & & 11 & \\
\hline Blackgram-Boro-Fallow & - & - & 12 & & \\
\hline Fallow-Ground Nut-Fallow & 16 & 7 & & & 4 \\
\hline Fallow-Blackgram-Boro & 16 & - & & & \\
\hline T. aman-Onion-Millet & 7 & - & & & \\
\hline T. aman-Boro-Jute & 6 & - & & & \\
\hline T. aman-Blackgram- Jute & 5 & - & & 4 & 2 \\
\hline T. aman-Groundnut-Jute & - & & & & 1 \\
\hline T. aman-Vegetables-Jute & - & & & & 1 \\
\hline T. aman-Blackgram- Boro & - & & & & 4 \\
\hline T. aman-Fallow-Jute & 4 & - & 2 & & \\
\hline T. aman- Fallow-Boro & 4 & 9 & 9 & 5 & 16 \\
\hline T. aman-Onion-Jute & - & 9 & & & 6 \\
\hline T. aman-Onion-Groundnut & - & & & & 5 \\
\hline T. aman-Potato-Groundnut & - & & & & 8 \\
\hline T aman-Mustard-Boro & 2 & 3 & 26 & 20 & \\
\hline $\mathrm{T}$ aman-Vegetables & 2 & - & - & - & - \\
\hline Fallow-Groundnut-Millet & 2 & - & - & - & - \\
\hline Fallow-Pulse/Blackgram-Fallow & 2 & - & - & - & - \\
\hline Fallow-Mustard-Jute & 1 & - & - & - & - \\
\hline
\end{tabular}


Table A2. Cont.

\begin{tabular}{|c|c|c|c|c|c|}
\hline \multirow{3}{*}{ Cropping Pattern } & \multicolumn{5}{|c|}{ Different Administrative Unit of Kurigram } \\
\hline & KurigramSadar & Chilmari & Nageswari & Bhurungamari & Ulipur \\
\hline & \multicolumn{5}{|c|}{$\%$ Acreage } \\
\hline Fallow-Maize-Jute & - & 2 & - & - & \\
\hline Fallow-Maize-Fallow & - & & - & - & 3 \\
\hline Fallow-Onion-Veg (China) & - & 2 & - & - & - \\
\hline T aman-Maize- Fallow & 1 & - & 2 & 3 & - \\
\hline T aman-Mustard-Jute & - & - & - & 2 & - \\
\hline $\mathrm{T}$ aman-Brinjal-Jute & - & - & - & - & 4 \\
\hline T amam-Khesari-Jute & - & 2 & - & - & - \\
\hline T aman-Maize- Sesbania & - & 2 & - & - & - \\
\hline Blackgram-Fallow-Jute & 1 & 6 & 4 & - & - \\
\hline Blackgram-Wheat-Jute & - & 1 & & - & - \\
\hline
\end{tabular}

Table A3. Cropping Pattern practiced in different administrative unitof Rangpur district.

\begin{tabular}{|c|c|c|c|c|}
\hline \multirow{3}{*}{ Cropping Pattern } & \multicolumn{4}{|c|}{ Different Administrative Unit of Gaibanda } \\
\hline & Pirgacha & Gongachora & Hatibandha & Kaunia \\
\hline & \multicolumn{4}{|c|}{$\%$ Acreage } \\
\hline T. aman-Potato-Groundnut & 46 & 13 & 12 & 30 \\
\hline T. aman-Maize-Fallow & 23 & 40 & 55 & 5 \\
\hline T. aman-Maize-Groundnut & & - & 15 & \\
\hline T. aman-Maize-Jute & - & - & - & 4 \\
\hline T amam-Tobacco-Maize & - & 13 & - & - \\
\hline Fallow-Potato-Jute & 18 & - & - & - \\
\hline $\mathrm{T}$ aman-Sweet gourd-Fallow & - & 12 & - & - \\
\hline Fallow-Tobacco-Jute & - & 5 & - & - \\
\hline T. amam-Potato-Jute & - & 5 & - & - \\
\hline T. amam-Potato-Fallow & - & - & - & 6 \\
\hline T. amam-Wheat-Jute & - & - & 3 & 18 \\
\hline T aman-G. Chili-Maize & - & - & - & 10 \\
\hline T aman-G. Chili-Groundnut & - & - & - & 8 \\
\hline T aman-G. Chili-Fallow & - & - & - & 12 \\
\hline Fallow-Tobacco-Fallow & - & 3 & - & - \\
\hline $\mathrm{T}$ aman-Onion-Jute & - & 3 & - & 1 \\
\hline $\mathrm{T}$ aman-Potato-Maize & - & 2 & - & - \\
\hline $\mathrm{T}$ aman-Tobacco-Jute & - & 2 & - & - \\
\hline $\mathrm{T}$ aman-Chili-Fallow & - & 1 & 4 & - \\
\hline Fallow-Onion-Fallow & - & 1 & - & - \\
\hline Fallow-Onion-Jute & 5 & - & - & 1 \\
\hline $\mathrm{T}$ aman-Potato-Brinjal & 4 & - & - & - \\
\hline T. aman- Green chili-Jute & 4 & - & 10 & - \\
\hline
\end{tabular}

Table A4. Cropping Pattern practiced in different administrative unitof Lalmonirhat district.

\begin{tabular}{cccc}
\hline & \multicolumn{3}{c}{ Different Administrative Unit of Lalmonirhat } \\
\cline { 2 - 4 } Cropping Pattern & LalmonirhatSadar & Aditmari & Kaliganj \\
\cline { 2 - 4 } & & \% Acreage & 70 \\
\hline T. aman-Maize-Fallow & 38 & 30 & 12 \\
T aman-Potato-Groundnut & 13 & 30 & 13 \\
T aman-Tobacco-Jute & 11 & 30 & 5 \\
Taro corms-Potato & - & - & - \\
T aman-Potato-Potato & 10 & - & 5 \\
\hline
\end{tabular}


Table A4. Cont.

\begin{tabular}{cccc}
\hline & \multicolumn{3}{c}{ Different Administrative Unit of Lalmonirhat } \\
\cline { 2 - 4 } Cropping Pattern & LalmonirhatSadar & Aditmari & Kaliganj \\
\cline { 2 - 4 } & & \% Acreage & - \\
T. aman-Maize- Boro & 4 & - & - \\
T aman-Onion-Jute & 4 & - & - \\
Fallow-Potato-Boro & 3 & - & - \\
T aman-Tobacco-Maize & 3 & - & - \\
T aman-Tobacco-Groundnut & 3 & - & - \\
T. aman- Maize- Jute & 3 & - & - \\
Sugarcane- & 2 & - & - \\
T aman-Potato-Maize & 1 & - & - \\
T aman-Potato-Jute & 1 & - & - \\
T aman-Maize-Groundnut & 1 & 10 & - \\
T aman-Green Chili-Jute & 1 & & \\
Fallow-Onion-Fallow & 1 & & \\
\hline
\end{tabular}

\section{References}

1. Sarker, M.H.; Haque, I.; Alam, M.; Koudstaal, R. Rivers, chars and char dwellers of Bangladesh. Int. J. River Basin Manag. 2003, 1, 61-80. [CrossRef]

2. $\quad$ Rogers, K.G.; Syvitski, J.P.M.; Overeem, I.; Higgins, S.; Gilligan, J.M. Farming practices and anthropogenic deltadynamics. In Deltas: Landforms, Ecosystems and Human Activities, Proceedings of the HP1, IAHS-IAPSO-IAPEI, Assembly, Gothenberg, Sweeden, 23 July 2013; IAHS Press: Wallingford, UK, 2013; pp. 133-142.

3. Rahman, S. Six decades of agricultural land use change in Bangladesh: Effects on crop diversity, productivity, food availability and the environment, 1948-2006. Singap. J. Trop. Geogr. 2010, 31, 245-269. [CrossRef]

4. Ashley, S.; Kat, K.; Hossain, A.; Nandi, S. The Chars Livelihood Assistance Scoping Study Final Report; DFID: Dhaka, Bangladesh, 2000; pp. 1-49.

5. Soil Resource Development Institute (SRDI). Land and Soil Resource Utilization Guide (Upazila Nirdeshika, in Bengali); Soil Resource Develop Institute (SRDI): Dhaka, Bangladesh, 2012; pp. 1-274.

6. Ahmed, A.U.; Ahmad, K.; Chou, V.; Hernandez, R.; Menon, P.; Naeem, F.; Naher, F.; Quabili, W.; Sraboni, E.; Yu, B. The Status of Food Security in the Feed the Future Zone and Other Regions of Bangladesh: Results from the 2011-2012 Bangladesh Integrated Household Survey. International Food Policy Research Institute Bangladesh Policy Research and Strategy Support Program for Food Security and Agricultural Development. 2013. USAID Grant Number:EEM-G-00-04-00013-00. Available online: http:/ / ebrary.ifpri.org/cdm/singleitem/collection/p15738co112/id/127518/rec/2 (accessed on 18 October 2021).

7. Karim, M.A. Upscaling Mungbean-Rice Pattern in the Charlands of Kurigram. In Pilot Project Final Report; Krishi Gobeshona Foundation-World Bank; Bangladesh Agricultural Research Council Complex: Dhaka, Bangladesh, $2014 ;$ pp. 1-47.

8. Sarker, U.K.; Monira, S.; Uddin, M.R. On-farm Evaluation and System Productivity of Wheat-Jute-T. aman Rice Cropping Pattern in Char Area of Bangladesh. Agric. Sci. 2020, 2, 39-46.

9. Hoque, M.Z.; Haque, M.E. Farming practices in selected charland of Bangladesh: Problems and opportunities. Ann. Bangladesh Agric. 2011, 15, 136-146.

10. Karim, M.A.; Quayyum, M.A.; Samsuzzaman, S.; Higuchi, H.; Nawata, E. Challenges and Opportunities in Crop Production in Different Types of Char Lands of Bangladesh: Diversity in Crops and Cropping. Trop. Agric. Dev. 2017, 61, 77-93.

11. Sarker, M.I. Causes and possible solutions of seasonal foodinsecurity (Monga) perceived by char dwellers in Bangladesh. Int. J. Ecol. Dev. Res. 2016, 1, 002-009.

12. Shahiduzzaman, M.; Rahman, M.Z.; Hoque, M.J.; Arefin, M.S. Food security condition of landless people in a char area of Rangpur district. Prog. Agric. 2013, 24, 281-289. [CrossRef]

13. Islam, M.S.; Sultana, S.; Saifunnahar, M.; Miah, M.A. Adaptation of char livelihood in flood and river erosion areas through indigenous practice: A study on Bhuapur riverine area in Tangail. J. Environ. Sci. Nat. Resour. 2014, 7, 13-19. [CrossRef]

14. Saifullah, N.M. Char Dwellers' Adaptation to Climate Change. Master's Thesis, BRAC University, Dhaka, Bangladesh, 2010.

15. Hasan, N.M.; Hossain, M.S.; Islam, M.R.; Bari, M.A. Trend in Availability of Agricultural Land in Bangladesh; National Food Policy Capacity Strengthening Program (NFPCSP): Dhaka, Bangladesh; FAO: Rome, Italy, 2013; pp. 1-72.

16. Karim, M.A.; Haque, M.M.; Hamid, A. Concern, Opportunity and Strategic Research in Crop Sector under Climate Change Context in Bangladesh. In Rising Atmospheric CO2 and Crop Response. A Compendium of Published Works at BSMRAU; Bangabandhu SMR Agricultural University: Gazipur, Bangladesh, 2014; pp. 1-64.

17. Mahmudul, H.A.Z.; Ishida, A.; Taniguchi, K. The Role of Farmers' Education on Income in Bangladesh. 2003, pp. 29-35. Available online: https:/ / www.lib.shimane-u.ac.jp/ (accessed on 11 August 2021). 
18. Asadullah, M.N.; Rahman, S. Farm Productivity and Efficiency in Rural Bangladesh: The Role of Education Revisited; The Centre for the Study of African Economic Working Paper Series, CSAE WPS/2005-10; Taylor \& Francis: Oxfordshire, UK, 2005 ; pp. 1-35.

19. Center for Environmental and Geographic Information Services (CEGIS). Riverine Chars in Bangladesh: Environmental Dynamics and Management Issues; The University Press Limited: Dhaka, Bangladesh, 2000; pp. 1-88.

20. Center for Resources Development (CRD). Report of the Baseline Survey of Agricultural Conditions in Kurigram District; CRD Report; CRD: Dhaka, Bangladesh, 2008; pp. 1-263.

21. Benson, C.; Clay, E.J. The Impact of Drought on Sub-Saharan African Economies: A Preliminary Examination; World Bank Technical Paper; World Bank: Washington, DC, USA, 1998.

22. Ahmed, Z.; Guha, G.S.; Shew, A.M.; Alam, G.M.M. Climate change risk perceptions and agricultural adaptation strategies in vulnerable riverine charislands of Bangladesh. Land Use Policy 2021, 103, 105295. [CrossRef]

23. Yadav, S.; Mondal, M.K.; Shew, A. Community water management to intensify agricultural productivity in the polders of the coastal zone of Bangladesh. Paddy Water Environ. 2020, 18, 331-343. [CrossRef]

24. Zaman, M.A.U.; Pramanik, S.; Parvin, N.; Khatun, A. Crop Diversification in Rangpur Region. Bangladesh Rice J. $2017,21,255-271$. [CrossRef]

25. Hamid, A.; Ullah, M.J.; Mollah, M.F.H.; Akbar, M.A. Traditional rice varieties perform better in tidal floodplain. Int. J. Adv. Res. 2015, 3, 1316-1321. 